\title{
屋外街頭ビジョンがある駅前交差点周辺の景観評価を規定する要因 FACTORS INFLUENCING LANDSCAPE EVALUATIONS AROUND AN INTERSECTION IN FRONT OF A STATION WITH OUTDOOR STREET VISONS
}

\author{
熊澤貴之*1, 高田大稀*2 \\ Takayuki KUMAZAWA and Daiki TAKADA
}

\begin{abstract}
Landscape simulation experiments on the intersection in front of the station were conducted using a 1:100 model, in which physical environmental factors of installed street vision were changed. Then, the factors that prescribe landscape evaluation are quantitatively examined based on 4 scales. A comfortable feeling is maximum with the installation ratio of the street vision of $2 \%$. The installation ratio $5 \%$ to $5.5 \%$ is an equilibrium point that satisfies 4 scales. When this level is exceeded, the downside is conspicuous in terms of cohesiveness and comfort. It is the limit of the allowable range with the installation ratio of $8 \%$.
\end{abstract}

Keywords : Outdoor Street Vision, Digital Signage, Landscape Evaluations, Outdoor advertisement, Station, Landscape guidelines 屋外街頭ビジョン，デジタルサイネージ，景観評価，屋外広告物，駅，景観ガイドライン

\section{1. 研究の背景及び目的}

近年, ディスプレイの大型化に伴い, ターミナルとなる駅前交差 点の周辺に屋外街頭ビジョン（以下, 街頭ビジョンと表記）の設置 が相次いでいる．街頭ビジョンは全国に約 110 基以上設置されてお $り^{11}$, その中で最大の街頭ビジョンは渋谷駅スクランブル交差点に 設置されているシブ八チヒットビジョン2)である，その大きさは高 さ $17.3 \mathrm{~m} \times$ 幅 $24.3 \mathrm{~m}$ である. ディスプレイが大きい街頭ビジョンは, 送り手の情報を歩行者や信号待ちの滞留者にわずかな時間で発信す ることができる. 送り手は映像に情報を載せて伝達することで, 歩 行者や滞留者の視線を奪っており, 様々な屋外広告物が歩行者及び 滞留者の視線誘導を連鎖的に誘発している. 彼らは街頭ビジョンを 注視することで足元周辺の注意力が散漫となり, 他者と接触や衝突 する問題を起こしている. 街頭ビジョンの設置数が年々増加する中, 視線誘導の錯綜には, 街頭ビジョンの数や大きさなどが大きく影響 すると考えられ，街頭ビジョンがある景観評価を規定する要因を定 量的に明らかにした上で適切な景観として維持できるように, 指標 を示す必要がある。

しかしながら, 街頭ビジョンの設置に制限を加えるルールは十分 に整っていない，既存の景観デザインガイドラインや屋外広告物条 例等では, 街頭ビジョンを屋外広告物の一部として扱っており, 屋 外広告物と同様の設置規制はあるものの, 街頭ビジョンが持つ特徴,
すなわち, 光源としての輝度の発散を考慮した規制及び放映の条件 等の規定は明記されていない. 渋谷区の景観ガイドライン 3) では, 建築物及び広告物についての設置規制及び色彩規制等が詳細に定め られている. しかし, 映像コンテンツを媒体とする街頭ビジョンを 含めたデジタルサイネージに関する設置規制や放映を含めた運営規 制については明記されていない。そもそも, 街頭ビジョンは映像媒 体であるため, 屋上広告塔や壁面広告, 懸垂幕などの既存の屋外広 告物とは異なるものであるため, 街頭ビジョンに関する景観形成基 準を策定するべきである.

屋外広告物やデジタルサイネージに関する既往研究としては, 加 藤ら ${ }^{4)}$ は, 屋外広告物のなかで映像コンテンツを表示媒体とするデ ジタルサイネージに着目し, 形態ごとの分類, 設置業種による分布 を調査したが, 街頭ビジョンのような大型のものを扱っていない. 松下ら ${ }^{5)}$ は, 街頭ビジョンが地域情報発信ツールとして有用とし, 運営方針や設置目的などの実態調査を行い, 今後の災害時の情報の 伝達において大型ビジョンの可能性を検討しているが，運営の実態 調查に留まっている．都市及び駅前空間における知覚に関する既往 研究としては, 山口ら ${ }^{6)}$ は, 駅前空間における多様な物理的要素を 分析しているが, 扱っている景観の構成要素の中に街頭ビジョンは 含まれておらず，街頭ビジョンを含む駅前空間での景観評価には至 っていない，清水ら ${ }^{7)}$ は，屋外広告物の見え方に着目し，一瞬で注
*1 茨城大学工学部都市システム工学科 准教授・博士 (工学)

*2 中央コンサルタンツ(株) 修士 (工学)
Assoc. Prof., College of Engineering, Ibaraki Univ., Dr.Eng. Chuoh Consultants Co., Ltd., M.Eng. 
視に值する広告物の諸条件を検討し，意識せずに自然に視界に入る 条件を明らかにしているが, 街頭ビジョンについては取り扱ってい ない，以上，街頭ビジョンがある景観と評価の関係を定量的に検証 した研究はない

そこで，街頭ビジョンのある景観を対象に，まず，人の評価の規 定要因を仮説として導き, 次に, 要因の水準を段階的に変化させた 景観シミュレーション実験を行い，評価を規定する要因を定量的に 検証する．以上の知見に基づき，街頭ビジョンに関する景観形成指 標を示す.

日本で最初に設置された街頭ビジョンは 1980 年 4 月新宿アルタの アルタビジョンである。 その後，1989 年に原宿アストロが原宿八角 館ビル壁面に開設され，1999 年に原宿駅前にハイパービジョン原宿 IF が開設された． 2000 年には渋谷駅前にQ'S EYE が開設され，その 後, 109 フォーラムビジョンと続き, DHC Channe1 とグリコビジョン が開設され，渋谷駅八チ公口のスクランブル交差点が国内最大の街 頭ビジョン群となった。 2014 年にはシブハチビジョンが渋谷駅八チ 公前に開設され，街頭ビジョンの密集地となった（図 1, 図 2).

本研究では, 渋谷駅八チ公口のスクランブル交差点を対象に景観 シミュレーション実験を行う。ここは，渋谷八チ公広場を囲むよう に街頭ビジョン 5 基が設置されている. 本実験では，実在する街頭 ビジョンがある景観を基準に，対象空間よりも街頭ビジョンが多く 存在する水準と少なく存在する水準を段階的に設定した。 これはで きるだけ現実に近い実験環境をシミュレーション環境に設定するこ とで, 被験者が抱く違和感を払拭するためである. 他では, 駅前の 広場を囲むように街頭ビジョンを増設しても違和感がない対象地は なかったため, 渋谷駅八チ公口のスクランブル交差点を研究の対象 地として選定した。

本研究成果の適用範囲は, ターミナル駅前の広場に面した商業地 区を想定している．街頭ビジョン設置の目安は，視点場より中心か ら左右に 60 度開いた 120 度の範囲で街頭ビジョンを見ることができ る広場を囲うように建てられた建物群を想定している。

尚，街頭ビジョンがある景観評価を規定する要因の一つに放映さ れている映像コンテンツがあるが，本研究では紙面の関係上，取り 上げない，また，街頭ビジョンは光源であるため昼夜において見え 方に大きな差があるが，本研究では昼間を取り上げる．他の時間帯 における要因は別に検討する予定である. また, 本研究の予備実験 と本実験の被験者は茨城大学の大学生及び大学院生とした. 選定の 理由として, 渋谷駅の利用者や関係者は経験值によって対象の評価 にバイアスが生じる可能性が考えられた，そのため, 渋谷駅が生活 圏から遠く, 馴染みがなく, 特別な思い入れがないなど, 渋谷エリ アとは無関係の被験者を採用した. 今回の被験者層は 20 代であるが, 評価尺度項目に基づく刺激に対する知覚の反応は，他の世代と大き な違いはないように考えている. 只, 本研究成果は被験者層である 20 代の評価に基づくものであり，世代によって街頭ビジョンに対す る印象が異なることも想定されるため, 他の世代と違いに基づく分 析については別途，検討する予定である.

\section{2. モーションVR 映像を用いた予備実験に基づく景観評価の分析}

\section{1 方法}

図 1 に, 設定した対象範囲と視点場を示す。渋谷駅スクランブル

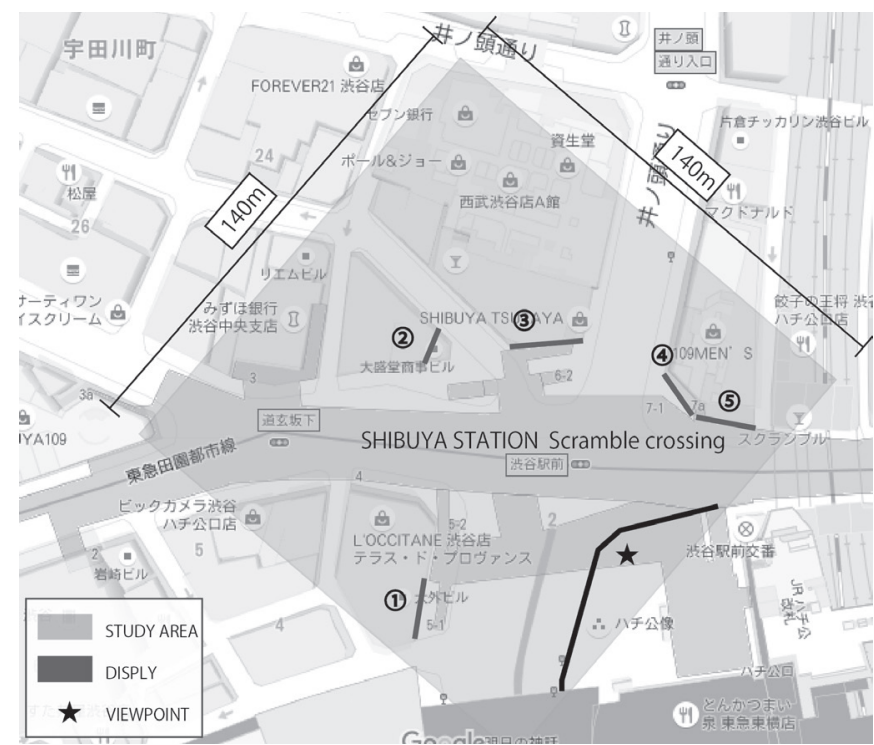

Fig. 1 STUDY AREA

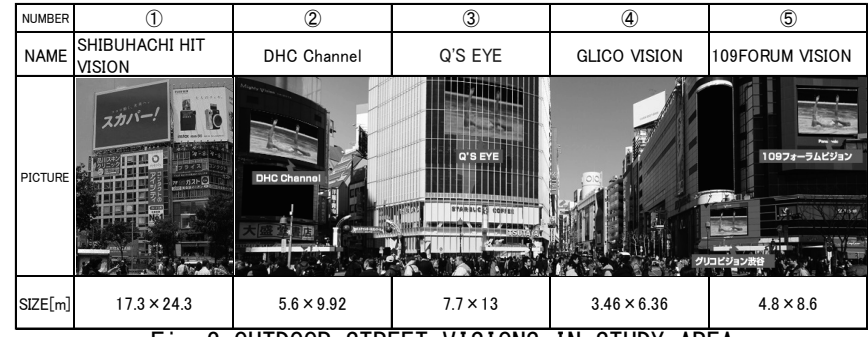

Fig. 2 OUTDOOR STREET VISIONS IN STUDY AREA

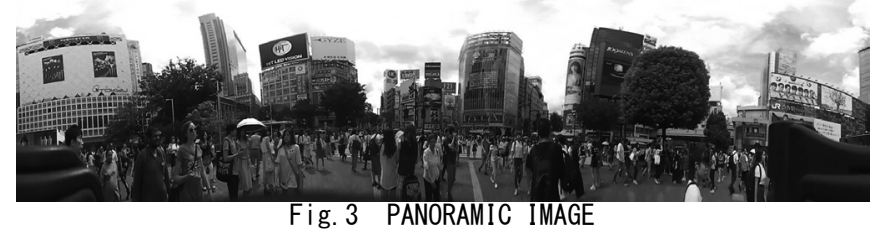

交差点に面した視点場から街頭ビ ジョンが視界に入るエリアを選定 した．視点場の選定では，街頭ビ ジョンがある駅前交差点周辺の景 観を全体的に眺めることができる 地点とした．実験の対象地として

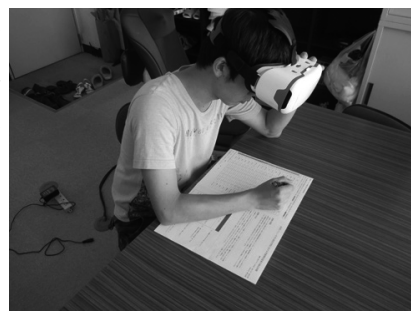
いる渋谷駅スクランブル交差点は, Fig. 4 A PICTURE OF EXPERIMENT 複数の街頭ビジョンに囲まれている空間であり, 同時に多くの他の 屋外広告物も存在している. 図 2 に, 対象範囲における街頭ビジョ ンの大きさを示す.

予備実験では, 次章以降の本実験で用いる要因の抽出や評価尺度 の抽出を目的とした．指定の視点場（図 1）から実際に現地の様子 を撮影した映像をもとにモーションVR 映像を作成し，ヘッドマウン トディスプレイ（以下，H.M. D. ）を用いて被験者に映像を見せ，景 観の疑似体験をさせ, 評価項目と評価視点を抽出した。具体的には, まず，対象区画内の星印の位置にてパノラマ撮影が可能な $360^{\circ}$ カ メラで，パノラマ動画を撮影した（図 3)。視点の高さは地上から $1.5 \mathrm{~m}$ とし，正午に行い，それぞれ明るさがあまり変動しない時間を 選び，撮影時間は 15 分間とした，次に，撮影した動画をもとに，動 画編集ソフトであるPIXPLO_SP360_4K を用いて，実験に使用する 5 分間のモーションVR 映像へ変換した。さらに，作成した映像を動画 
投稿サイトYouTube ヘとアップロードすることで，モーションVR 映 像を視聴できる環境を整えた. H. M. D. ( 図 4) でモーションVR 映像 を見る時, 見る人の注視先に応じて映像が連動する.これによって 現地にいるかのような状態で景観を見ることが可能になるため, 要 因や評価尺度を抽出する精度が向上寸ることを狙いとしている.

予備実験の被験者は茨城大学の大学生及び大学院生 18 名であっ た. 実験は 1 人ずつ行い, 要因の抽出及び印象評価に要した時間は 15 分程度であった. 実験は, 2017 年 8 月 1 日から 8 月 8 日にかけて 実施した。実験の流れは以下の通りである. まず, 被験者に映像を 5 分間見せ, 次に, 景観の中で印象に残った項目を自由に記述させ（評 価項目の抽出), さらに, 項目を選んだ理由を具体的に記述させ（評 価視点の抽出), 良悪の判断を選択させ (評価の抽出), 最後に, 改 善する若しくはより良くするための改善策を具体的に記述させた (改 善策の抽出). その後, 実験者は抽出された評価視点と大井らが景観 評価尺度の標準化に関する研究 ${ }^{8)}$ で整理した SD 尺度を比較し, 本 研究の対象地の評価に適した 12 の評価尺度を選定した. その後, 12 の各評価尺度に 7 段階を設け, 評価実験を実施した。

\section{2 評価項目に基づく要因の抽出}

表 1 に, 抽出された評価項目と評価視点の一覧を示す. 評価項目 は「街頭ビジョン」「看板等の壁面広告」「建物」「人」「屋上広告塔」 の順に多く, 数が多く乱雑であるなど, 悪い評価が多いことが把握 された，渋谷のスクランブル交差点周辺には, 街頭ビジョン, 壁面 広告や屋上広告塔などの多種類の広告物が存在している。そのため, 意識していなくても何らかの広告物が視界に入る状態となっている. また，これらの広告物に関しては悪い評価をする回答が多く見られ， 街頭ビジョンに関しても同様の傾向が見られた．街頭ビジョンから 受ける情報は非常に多く, 広告を発信する側は見る人の印象に残る 工夫をしているが，その反面，音がうるさい，まぶしいなどのマイ ナス面の影響も存在していた。 また，建物については不統一である ことが指摘されており, 人については, 多くの人で混雑しているこ とが指摘されている.これらについても景観の特徵と考えられるが, 予備実験結果の表 1 では屋外広告物が上位に位置していることから, 屋外広告物に焦点を絞ることとし, 本実験で, 建物の形態と人の混 雑状態は共通な条件として同一になるように統制した。 よって, 街 頭ビジョンがある景観評価を規定する要因として, 街頭ビジョンや 壁面広告, 屋上広告塔を本実験で取り上げる要因とした。またこれ らの評価（表 1）はネガティブであったことから，本実験では現況 を各要因のネガティブな水準として設定した。一方, 本実験の各要 因で取り上げるポジティブな水準として現状の設置状況を改善する 水準を設定した。 このように, 本実験では三つの要因に現状を基準 に考慮したネガティブな水準と現状を改善したポジティブな水準を 設定し，検証した。

\section{3 評価尺度による評価実験結果の考察}

選定された 12 の評価尺度は「面白い一退屈な, 派手な一地味な, 騒々しい一物静かな, 賑やかな-閑散とした, 暖かい一冷たい, 明 るい一暗い, 迫力のある-迫力のない, 理想的な-現実的な, 深み のある-味気ない, 美しい一醜い, 快適である-不快である, まと まっている-乱雑である」である. 評価実験では, モーションVR 映 像を 5 分間見せた後, 被験者に各尺度の 7 段階評定の該当する箇所 に記しを付けさせた，本実験では，景観シミュレーションのパター
Table 1 LIST OF EXTRACTED EVALUATION ITEMS AND VIEW POINTS

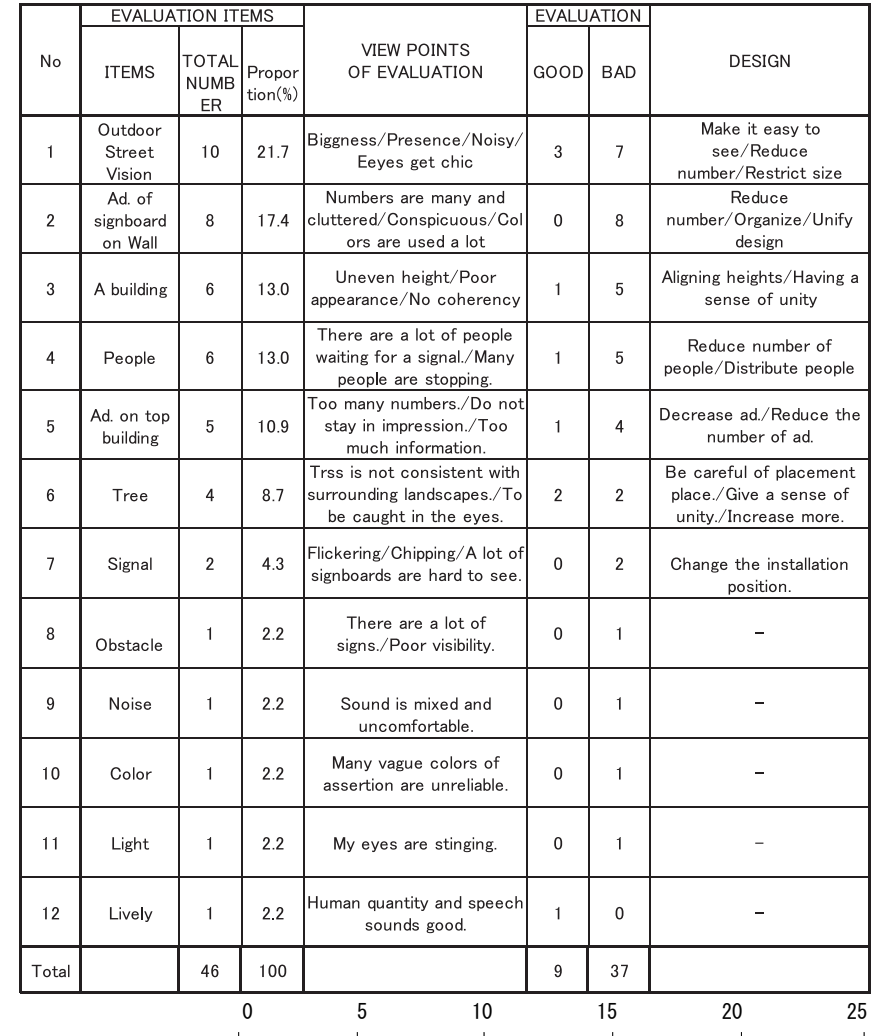

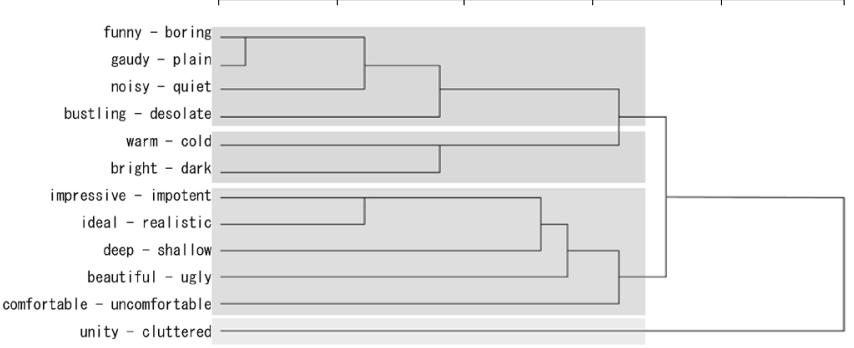

Fig. 5 RESULTS OF CLUSTER ANALYSIS FOR EVALUATION SCALES

ン数が多いため, 被験者から 12 の全ての評価項目に対する評価值を 得た場合に時間を要す。そこで，本実験で使用する評価尺度を厳選 するため, 12 の評価尺度に対してクラスター分析を実施し, 分類し た. 分析では, 全被験者が評価した各尺度における段階を得点化し, クラスター分析を実施した。 図 5 に評価尺度のクラスター分析の結 果を示寸. クラスターは, 大きく分けて 4 つから構成された. クラ スター 1 は [面白い, 派手な, 騒々しい, 賑やかな ] であり, 賑や かさを示寸尺度と考えた。 クラスター 2 は［暖かい，明るい］から 構成されており，明るさを示寸尺度とした．クラスター 3 は [ 迫力 のある，理想的な，深みのある，美しい，快適である]から構成さ れており, 快適感と解釈された. その他に独立するクラスターとして, 「まとまっている」がある，以上より,本実験で用いる評価尺度を,「賑 やか感」「明るさ感」「快適感」「まとまり感」とした。

\section{3. 景観シミュレーション装置を用いた実験による評価の規定要因}

\section{1 実験装置の概要}

前章の予備実験の結果（表 1), 抽出された街頭ビジョンは, 実在 環境では, 光源からの発光体の色で情報を伝達している. 一般的に, 人間が知覚する色には大きく分けて表面色と光源色がある．表面色 
は反射物体の色, 光源色は発光体の色であり, 表面色と光源色はそ れぞれ性質が異なる色として取り扱われている ${ }^{9)}$. モーションVR 映 像を用いた予備実験の方法は, 広場を囲んだ景観を対象に, 視野角 を自在に操りながら良い景観や悪い景観の要素を抽出するには適し ていたが, 表面色や光源色といった区別を加味した方法ではない. 本章における本実験では, 街頭ビジョンや看板等の壁面広告, 屋上 広告塔を要因として取り上げるため, 表面色や光源色による視覚情 報伝達の差が加味される必要がある. 街頭ビジョンを要因として取 り上げる場合, ディスプレイから発光する状況を考慮した光源色モ ードでの知覚環境が適している. また, 他の屋外広告物は表面色で あることが多いため, 表面色モードでの知覚環境が適している.

そこで，本実験では，光源色と表面色での知覚を再現した実環境 に近い状況と寸るため, 図 1 に示寸研究対象の範囲を縮尺 $1 / 100$ の 模型で再現し, 街頭ビジョンについてはディスプレイを埋め込み, 光源色モードとし, 壁面や壁面広告, 屋上広告塔は視感測色に基づ いて壁面の色彩を再現した。表 2 に, 模型による景観シミュレーシ ヨン装置の作成方法を示す。現地における実測調査では建物壁面の 視感測色，建物壁面の撮影，樹木と街灯を調查した。 2017 年 7 月 28 日（木）の正午にかけて渋谷駅周辺にて現地調查を行った. 調查日 の天気はくもり, 気温 29 度, 風は南 $19 \mathrm{~km} / \mathrm{h}$, 湿度 $65 \%$, 雲量 $84 \%$ であった。色彩を再現するために色票を用いて建物壁面の視感測色 を行った. 視感測色の際, 各建物で見え方の条件が異ならないように, 建物から $3 \mathrm{~m}$ 離れた位置から測定し，色票を照らし合わせ，色相，明 度, 彩度の数值を調査シートに記入した。

図 6 に視感測色を実施した建物壁面のマンセル值を示す。次に測 定したマンセル值に模型の立面図の色彩を一致させた。ささらに，模 型にディスプレイを設置するため, 実際に設置されている各街頭ビ ジョンのサイズの調查を行い, 実験装置で用いるディスプレイを選 定した. 表 3 に, 街頭ビジョンサイズ及び実験装置で使用したディ スプレイのサイズを示す.

図 7 に, 建物の立面図の作成方法を示す。模型にて建物を再現す る際に, 建物壁面の写真を撮影した. 撮影の際, 建物全体が写る距 離まで下がり, 傾かないように配慮した。 また, 建物全体が 1 枚に 収まらない建物については, 分割して撮影した。しかし, 写真のゆ がみ補正を行う際に画質が落ちてしまうこと，撮影時に写りこんで しまう植栽を削除する過程で立面図に違和感が生じてしまうことか ら, 撮影した写真をそのまま使用することが不適切であると判断し た。 そこで，撮影した写真をもとに，トレース作業を行うことで模 型の壁面を再現した。壁面のトレースは，撮影した写真の縦横比を 補正したのちに，画像編集ソフトを用いることで作成した。このよ うな手順で, 対象範囲のす心゙ての建物の壁面をトレースした. さらに, 樹木の位置及び数, 街灯の位置及び数, 点字ブロックの位置, 地下 鉄の入口の位置, 喫煙スペースの位置を記録し, 模型にて, 植栽及 び街頭を再現した. また, 要因と水準のシミュレーションについては, 本実験の際に変更できるようにパーツを作成した.

図 8 に, 実験装置の断面図を, 図 9 にシミュレーション模型写真 を示す. 実験装置の寸法は幅 $1.4 \mathrm{~m} \times$ 奥行き $2.0 \mathrm{~m} \times$ 高さ $2.0 \mathrm{~m}$ であり， 周囲及び天井部分が暗幕で囲まれており, 実験装置内に設置した照 明に応じて照度を設定できるようになっている. 実験では昼光の明 るさを想定しており，上部に設けた光源ランプ 2 台，補助光源ラン

Table 2 METHOD OF MAKING LANDSCAPE SIMULATION DEVICE

How to make site model
(1) The experimenter performs site trace in study area.
$(2)$ The experimenter confirms building position of each section, and creates a road
and a crosswalk.
(3) The experimenter creates background in the experimental apparatus.
(4) The experimenter measures a height of each building. 0therwise, published
height data was used.
(5) The experimenter makes a model of the building.

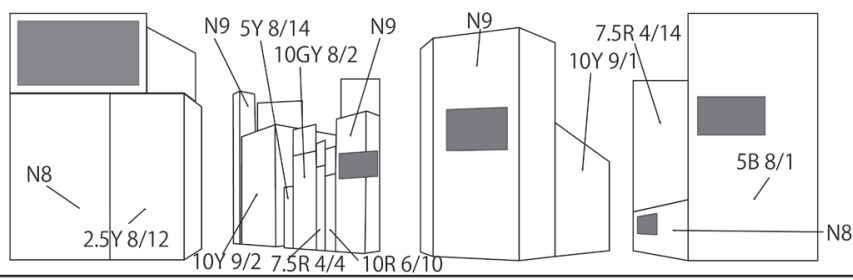

Fig. 6 RESULT OF VISUAL COLOR MEASUREMENT IN STUDY AREA Table 3 OUTDOOR STREET VISION SIZE AND EXPERIMENTAL DISPLAY

\begin{tabular}{|c|c|c|c|c|c|}
\hline NUMBER & (1) & (2) & (3) & (4) & (5) \\
\hline NAME & $\begin{array}{c}\text { SHIBUHACHI } \\
\text { VISION }\end{array}$ & DHC Channel & Q'S EYE & GLICO VISION & $\begin{array}{c}109 F O R U M \\
\text { VISION }\end{array}$ \\
\hline SIZE[m] & $17.3 \times 24.3$ & $5.6 \times 9.92$ & $7.7 \times 13$ & $3.46 \times 6.36$ & $4.8 \times 8.6$ \\
\hline $\begin{array}{c}\text { S:1/100 } \\
\text { inch }\end{array}$ & 11.8 inch & 4.6 inch & 6.0 inch & 2.8 inch & 3.9 inch \\
\hline $\begin{array}{c}\text { DISPLAY IN } \\
\text { EXPERIMENT }\end{array}$ & Surface Pro 3 & Android SO-04E & Nexus7 & iPod nano & iPod touch \\
\hline $\begin{array}{c}\text { DISPLAY } \\
\text { SIZE }\end{array}$ & 12 inch & 4.6 inch & 7.0 inch & 2.5 inch & 4.1 inch \\
\hline
\end{tabular}

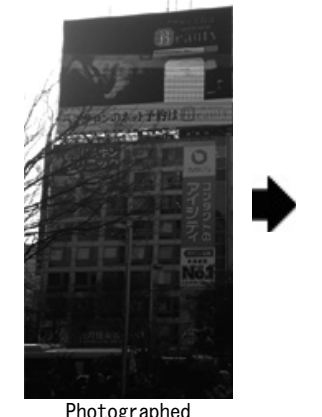

Photographed

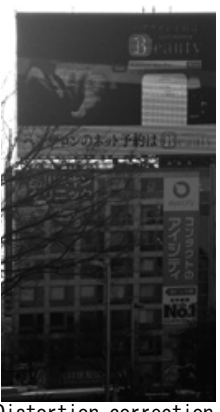

istortion correction

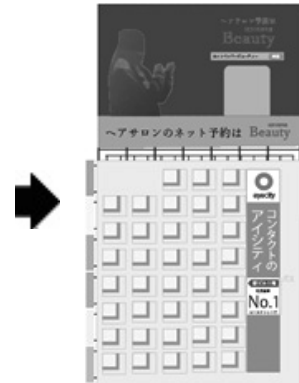

Coloring after tracing

Fig. 7 METHOD OF MAKING ELEVATIONS OF BUILDINGS

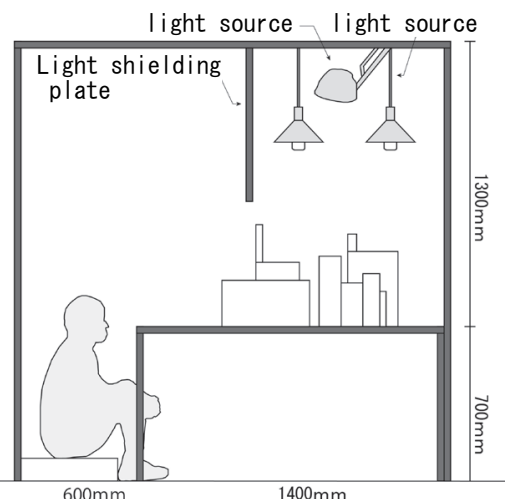

Fig. 8 SECTION PLAN OF THE EXPERIMENTAL DEVICE

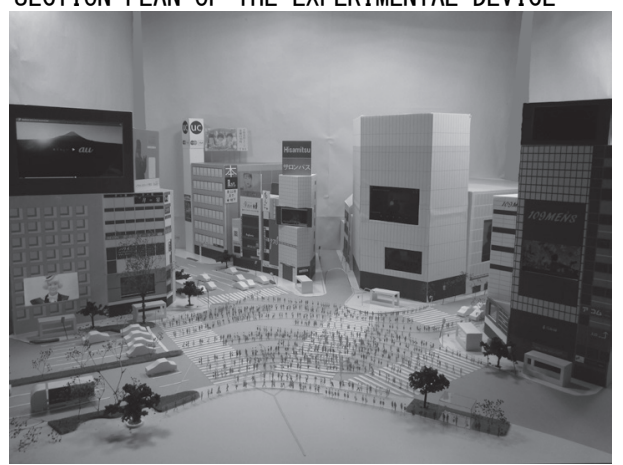

Fig. 9 INSIDE IN THE EXPERIMENTAL DEVICE 
プ 4 台を用いて水平面照度 $6,000 \mathrm{~lx}$ 程度を確保した. 視点の高さは 地上 $1.5 \mathrm{~m}$ 程度を想定し, 渋谷駅スクランブル交差点からの眺めとし た，視点場は，図 1 に示寸場所と同一にし，そこから眺められるよ うにした． 街頭ビジョンに映す映像については渋谷駅スクランブル 交差点で映し出されているものと類似した内容の物を使用した.

\section{2 実空間との差の検証}

本実験を行う前に, 景観シミュレーション装置がどの程度現実を 再現できているかを検証するために，現地景観と同じ場所の模型景 観に対し，予備実験で使用した 12 の評価尺度を用いて同一の視点場 からの景観評価を抽出した。 まず，正午前後の一分間に視点場から 景観を眺めた。 その後, 同一の 12 の評価尺度で同様に評価した。分 析では得られた尺度值を集計し，現地景観と模型景観の間で評価に 差が検出されるか $\mathrm{t}$ 検定で分析した. 被験者は予備実験と同様の茨 城大学の大学生及び大学院生 18 名であった. 図 10 に現地と模型に 対する評価尺度值の比較, 表 4 亿本実験で使用するまとまり感, 賑 わい感, 快適感, 明るさ感の 4 尺度に関しての $\mathrm{t}$ 検定の分析結果を 示す.

その結果，現地景観と模型景観の評価はほぼ類似しており，2 群間 に有意差が見られなかった。よって景観シミュレーション実験装置 における現地の再現性は高いことが確認され，実験装置の有効性が 検証された。これは渋谷駅八チ公口のスクランブル交差点に見られ る屋外広告物の特徴に基づき, 街頭ビジョンを光源色モードで, 他 を表面色モードで再現したことにより，人間が実環境で知覚する状 況と同じ状況を再現したことによる. 光源色モードと表面色モード9) によって再現した環境は現地に実環境に類似したことが確認された.

\section{3 実験の方法}

本実験では，街頭ビジョン，壁面広告，屋上広告塔を要因とし， それぞれに水準が設定された景観シミュレーション装置を用いて, 人にどのような影響を与えているか上述の 4 つの評価尺度に基づい て検証する. 実験の組み合わせは，4水準 (街頭ビジョン) $\times 2$ 水 準 (壁面広告) $\times 2$ 水準 (屋上広告塔) の 3 要因から成る計 16 パタ ーンとした，実験で用いる要因と水準に関しては，予備実験の印象 項目の結果から, 実験では要因として街頭ビジョン, 壁面広告, 屋 上広告塔の 3 つを使用した。 各水準は広告物のそれぞれの大きさや 形が異なり，数による定義では一般的な知見として有効でないと判 断したため，画像編集ソフトを用いたピクセル数の抽出により各水 準の建物ファサード全体に対する割合を算出し，視点場における建 物ファサードに対する屋外広告物の面積の割合を提示することで, 具体的な水準の值の検討を行った，各要因における水準の基準とし て, 現地景観における街頭ビジョンの建物ファサード全体に対する 割合, 現地景観における壁面広告の建物ファサード全体に対する割 合，現地景観における屋上広告塔の建物ファサード全体に対する割 合を採用した. 上記の表 5 に各水準のピクセル数で算出された割合 の結果を示す. 表 6 に, 各水準の建物ファサード全体に対する割合 を示す，その結果，街頭ビジョンに関しては，現在の設置割合は 8 \%であったが，予備実験結果の表 1 ではネガティブ評価であったた め，現況よりも増設した場合の設置割合 $14 \%$ を採用した．また，ポ ジティブな水準を設定としては， $8 \%$ を $1 / 4$ に減らした場合の設置割 合 $2 \%$, さらに減らした設置割合 $0 \%$ を採用し, 全部で 4 水準とした. 次に，壁面広告に関しては，予備実験結果の表 1 では，現状の壁面

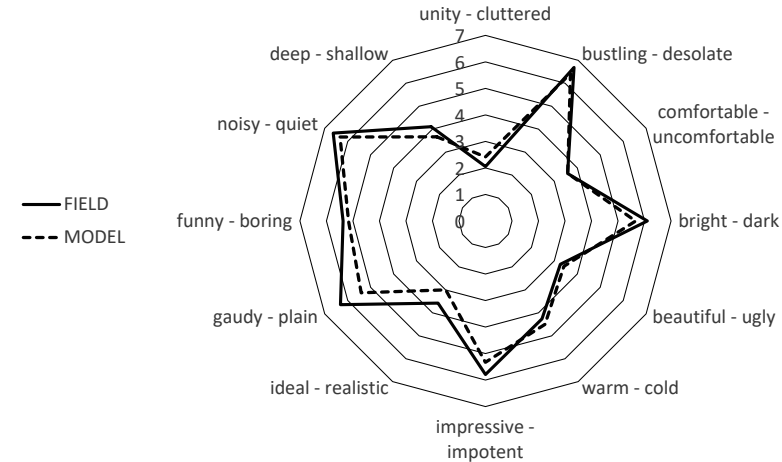

Fig. 10 LANDSCAPE EVALUATION IN FIELD AND MODEL

Table 4 DIFFEREMCE IN EVALUATION OF 4 SCALES T-TEST RESULT

\begin{tabular}{|c|c|c|c|c|c|c|c|}
\hline & \multicolumn{2}{|c|}{ AVERAGE } & \multirow{2}{*}{$\begin{array}{c}\text { LOWER } \\
\text { LIMIT }\end{array}$} & \multirow{2}{*}{$\begin{array}{c}\text { UPPER } \\
\text { LIMIT }\end{array}$} & \multirow{2}{*}{ T VALUE } & \multirow{2}{*}{ P VALUE } & \multirow{2}{*}{ JUDGMENT } \\
\hline & FIELD & MODEL & & & & & \\
\hline unity - cluttered & 2.05 & 2.42 & -0.956 & 0.228 & -1.258 & 0.218 & - \\
\hline bustling - desolate & 6.68 & 6.42 & -0.275 & 0.810 & 1.008 & 0.322 & - \\
\hline $\begin{array}{l}\text { comfortable - } \\
\text { uncomfortable }\end{array}$ & 3.58 & 3.58 & -1.110 & 1.101 & -0.008 & 0.993 & - \\
\hline bright - dark & 6.11 & 5.67 & -0.430 & 1.307 & 1.033 & 0.310 & - \\
\hline
\end{tabular}

Table 5 Number of pixels at each level on the screen

\begin{tabular}{|c|c|c|c|c|}
\hline \multirow{2}{*}{ PIXELS OF STREET VISION } & \multicolumn{4}{|c|}{ LEVELS } \\
\hline & $\begin{array}{c}\text { More than } \\
\text { Current }\end{array}$ & Current & $0.25 \times$ Current & $\begin{array}{c}\text { Less than } \\
0.25 \times \\
\text { Current }\end{array}$ \\
\cline { 2 - 5 } & 335,843 & 199,684 & 45,809 & 0 \\
\hline PIXELS OF AD. ON WALL & \multicolumn{2}{|c|}{ Current } & $0.25 \times$ Current \\
\cline { 2 - 5 } PIXELS OF AD. ON TOP BUILDING & \multicolumn{2}{|c|}{330,601} & 73,006 \\
\cline { 2 - 5 } & \multicolumn{2}{|c|}{86,913} & $0.25 \times$ Current \\
\hline PIXELS OF BUILDING ELEVATION & \multicolumn{4}{|c|}{$2,403,695$} \\
\hline
\end{tabular}

Table 6 PERCENTAGE OF ALL LEVELS TO TOTAL BUILDING VERTICAL

\begin{tabular}{|c|c|l|}
\hline \multirow{3}{*}{$\begin{array}{c}\text { STREET } \\
\text { VISION }\end{array}$} & Less than $0.25 \times$ Current & $0 \%$ of entire building elevations \\
\cline { 2 - 3 } & $0.25 \times$ Current & $1.91 \%$ of entire building elevations \\
\cline { 2 - 3 } & Current & $8.31 \%$ of entire building elevations \\
\cline { 2 - 3 } & More than Current & $13.97 \%$ of entire building elevations \\
\hline AD. ON WALL & $0.25 \times$ Current & $3.04 \%$ of entire building elevations \\
\cline { 2 - 3 } & Current & $13.75 \%$ of entire building elevations \\
\hline \multirow{2}{*}{$\begin{array}{c}\text { AD. ON TOP } \\
\text { BUILDING }\end{array}$} & $0.25 \times$ Current & $0.75 \%$ of entire building elevations \\
\cline { 2 - 3 } & Current & $3.62 \%$ of entire building elevations \\
\hline
\end{tabular}

Fig. 11 EXPERIMENTAL SITUATION

Table 7 FACTORS AND LEVELS OF EXPERIMENTS

\begin{tabular}{|c|c|c|c|c|c|c|c|}
\hline \multicolumn{2}{|c|}{} & \multicolumn{3}{|c|}{ LEVELS [AREA PERCENTAGE } & \multirow{2}{*}{ OF ENTIRE BUILDING ELEVATIONS] } & \multirow{2}{*}{ NUMBERS } & \multirow{2}{*}{ TOTAL } \\
\hline \multirow{3}{*}{ FACTORS } & STREET VISION & $0 \%$ & $2 \%$ & $8 \%$ & $14 \%$ & 4 & \multirow{3}{*}{16} \\
\cline { 2 - 7 } & AD. ON WALL & \multicolumn{2}{|c|}{$3 \%$} & \multicolumn{2}{|c|}{$14 \%$} & 2 & \multirow{2}{*}{$4 \%$} \\
\cline { 2 - 6 } & AD. ON TOP BUILDING & \multicolumn{2}{|c|}{$1 \%$} & \multicolumn{2}{|c|}{$4 \%$} & 2 & \\
\hline
\end{tabular}

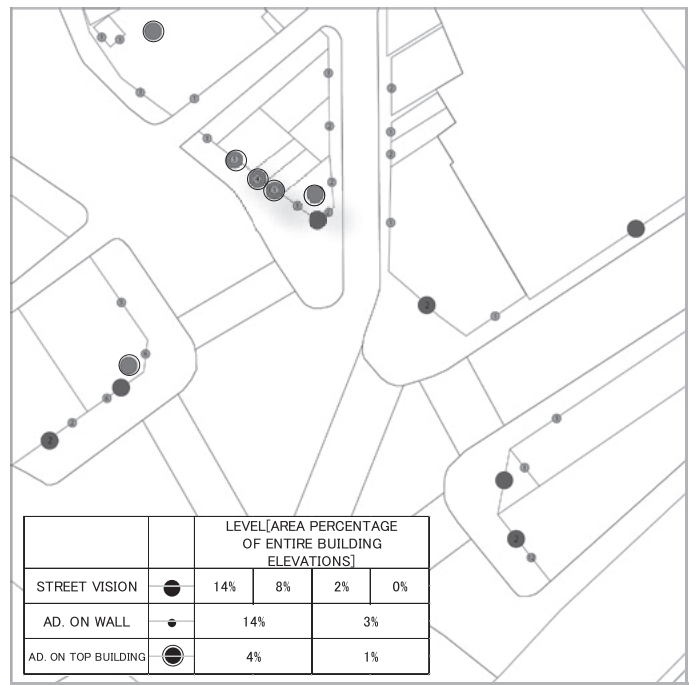

Fig. 12 POSITION OF Ad. ADJUSTED LEVEL IN EACH FACTOR 
広告に対し，景観を損衫る要因として悪い評価をしていることから， 現状の設置数をネガティブな水準として設定し, 設置割合 $14 \%$ とし た．ポジティブな水準としては，現状よりも $1 / 4$ に設置数を減らす ことで水準を設けることとし，設置割合 $3 \%$ とした，さらに，屋上 広告塔に関しては, 予備実験では, 現状の屋上広告塔に対し, 景観 を損初る要因としてネガティブ悪い評価をしていることから, 現状 の設置数をネガティブな水準として設定し, 設置割合 $4 \%$ とした. ポジティブな水準としては, 現状よりも $1 / 4$ に設置数を減らすこと で水準を設けることとし，設置割合 $1 \%$ 程度とした。

本実験では, 被験者を暗室脇の机一座らせ，次の教示文「まず始 めに, こちらの暗室内に入って中に設置してある模型を眺めてくだ さい. その後, 手元の評価シートに記載されているまとまり感, に ぎわい感, 快適感, 明るさ感の 4 つの尺度で評価してください. 評 価が終わったら暗室から一度出て, 待機してください, 再度暗室内 に入って, 中に設置してある模型を同様に評価してください。これ を全回繰り返します.」を与えた。被験者は暗室内で眺めた景観に対 してその場で該当する評価に印を付けた。実験者は被験者に一人づ つ定位置から眺めさせ，表 7 で示した実験計画法に基づく要因と水 準の 16 パターンの刺激をランダムな順序で一つづつ提示し，1つの 刺激を 1 分間被験者に見せた後，4つの評価尺度であるまとまり感， 賑わい感, 快適感, 明るさ感について, 7 段階評定で評価させた。 評価するのに要した時間は 40 分程度であった。実験は, 2017 年 10 月 13 日から 21 日に実施した. 本実験の被験者は茨城大学の大学生 及び大学院生 49 名であった. 図 11 に実験の様子を示す. 図 12 に, 各要因におけて水準を調整した広告物の位置を示す。図 13 に, 3 要 因から構成される景観シミュレーションの全パターンを示す。

\section{4 結果及び考察}

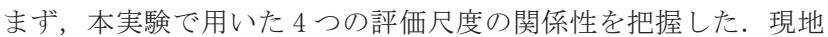
景観と同様の条件，すなわち，街頭ビジョンの設置割合 $8 \%$, 壁面 広告の設置割合 $14 \%$, 屋上広告塔の設置割合 $4 \%$ の場合にまとまり 感, 賑わい感, 快適感, 明るさ感の 4 つの尺度に対する相関分析を 行った。 その結果, まとまり感と賑わい感の相関係数は -0.233 , ま とまり感と快適感の相関係数は 0.162 , まとまり感と明るさ感の相 関係数は 0.027 , 賑わい感と快適感の相関係数は -0.115 , 賑わい 感と明るさ感の相関係数は 0.264 , 快適感と明るさ感の相関係数は -0.152 で, す心゙てにおいて有意差は検出されなかった. よって, 現 状の景観に対する評価においては, 尺度とした形容詞対相互の独立 性が確認された

次に, 全被験者のデータを得点化し, 要因と水準の組み合わせに 基づいて 3 元配置分散分析を行った. 表 8 にまとまり感を規定する 要因の結果を示寸，街頭ビジョンが $0 \%$ のきに正の最大值を，街 頭ビジョン $14 \%$ のときに負の最大值をとっており，街頭ビジョンの 割合が小さい程まとまりがあり, 大きい程乱雑に感じられることが 把握された $(\mathrm{F}(3,129)=159.5, \mathrm{p}<.01)$. 壁面広告は街頭ビジョン程で はないが，同様の傾向を示しており，視界に入る広告物の割合が大 きくなる程，まとまりが無くなることが把握された $(\mathrm{F}(1,129)=9.3$, $\mathrm{p}<.01)$. また, 街頭ビジョンと屋上広告塔 $(\mathrm{F}(3,129)=11.2, \mathrm{p}<.01)$ において交互作用が有意であったため, 単純主効果の検定を行った。 尚, 一般的な分散分析の手順に従って, 交互作用が有意であった組 み合わせに限り，別途に関係図を作成し考察した，以降の分析にお

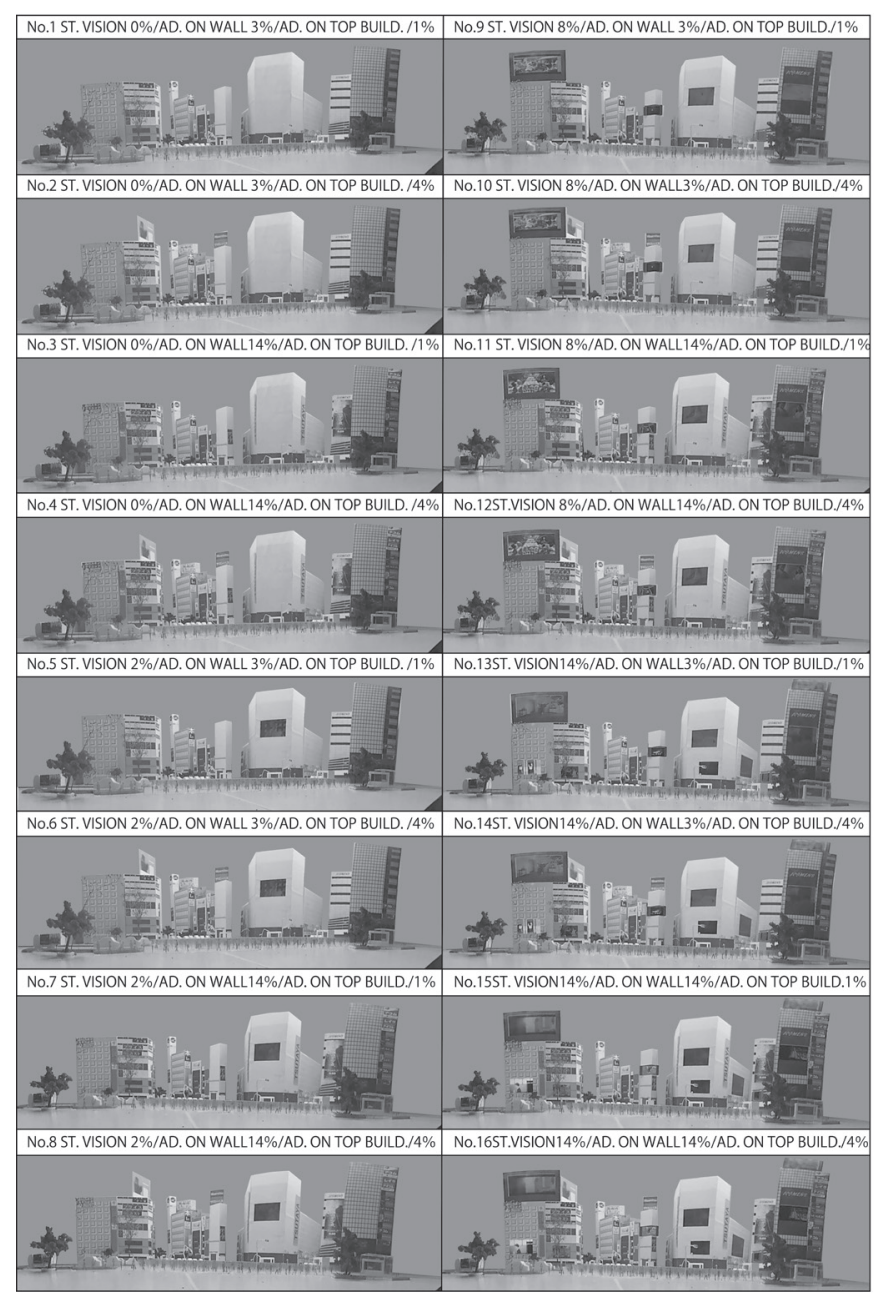

Fig. 13 TOTAL LANDSCAPE SIMULATION EXPERIMENT PATTERN Table 8 INFLUENCE FACTORS OF UNITY

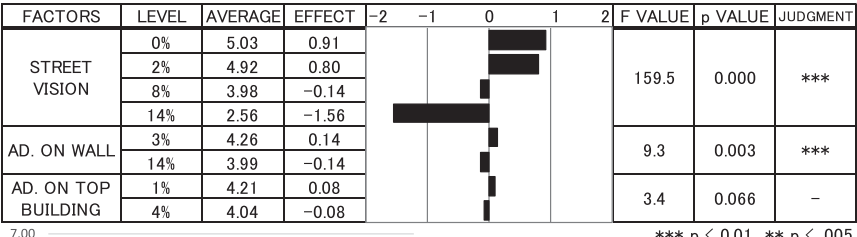

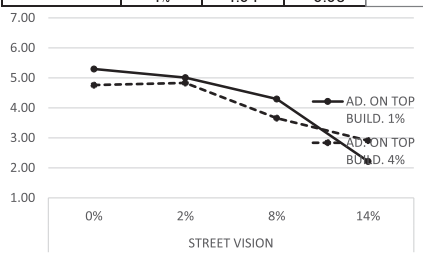

Fig. 14 UNITY BETWEEN VISION AND AD. ON TOP BUILDING Table 9 INFLUENCE FACTORS OF BUSTLING FEELING

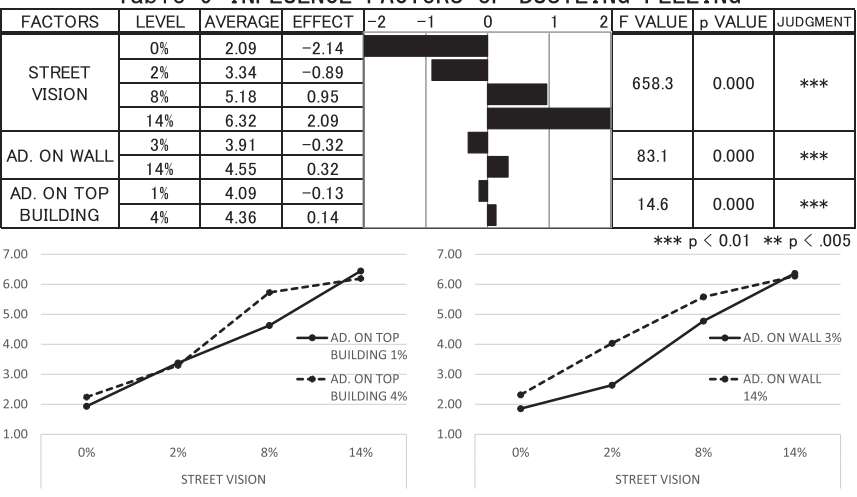

Fig. 15 BUSTLING BETWEEN VISION Fig. 16 BUSTLING BETWEEN VISION AND AD ON TOP BUILDING 
いても同様である. 図 14 に, 街頭ビジョンと屋上広告塔のまとまり 感の関係を示す，街頭ビジョンと屋上広告塔の関係は, 大方, 街頭 ビジョンが少なく, 屋上広告塔が少ない場合にまとまり感が高く, 街頭ビジョンが多く, 屋上広告塔が多い場合に, まとまり感が低い ことが確認された。視界に入る街頭ビジョンの割合が大きい場合に は，他の場合に比べてまとまり感が低減した。

表 9 に, 賑わい感を規定する要因の結果を示す. 街頭ビジョン $(\mathrm{F}(3,129)=658.3, \mathrm{p}<.01)$ ，壁面広告 $(\mathrm{F}(1,129)=83.1, \mathrm{p}<.01)$ ，屋 上広告塔 $(\mathrm{F}(1,129)=14.6, \mathrm{p}<.01)$ のすべての要因において主効果が 有意であった，街頭ビジョン $0 \%$ のきに負の最大值を, 街頭ビジ ヨンが $14 \%$ のきに正の最大值をとっており，街頭ビジョンが少な いほど閑散とし，多い程賑やかに感じられることが分かった。また， 壁面広告, 屋上広告塔も同様の傾向を示しており, 屋外広告物が多 く存在する空間ほど賑わい感が増す結果となった。また, 街頭ビジ ヨンと屋上広告塔の交互作用 $(\mathrm{F}(3,129)=16.9, \mathrm{p}<.01)$, 街頭ビジョ ンと壁面広告の交互作用 $(\mathrm{F}(3,129)=21.5, \mathrm{p}<.01)$ が有意であったた め, 単純主効果の検定を行った。 図 15 に, 街頭ビジョンと屋上広告 塔の賑わい感を示す．評価值の推移を見ると，街頭ビジョンが $0 \%$, $2 \% ， 14 \%$ のき, 屋上広告塔の変化に有意差が見られなかった。こ れは, 街頭ビジョンが屋上広告塔に比べて目立っていることが原因 であると考えられる. 上記の組み合わせでは, 街頭ビジョンの印象 が強く残るため, 屋上広告物はあまり印象に残らないと推察される. 図 16 に, 街頭ビジョンと壁面広告の賑わい感の関係を示す. 評価值 の推移を見ると, 街頭ビジョン $14 \%$ のとき, 壁面広告物の変化に有 意差が見られなかった．これは，視界に入る街頭ビジョンの割合が 大きくなることで，付近に設置してある壁面広告に意識が向かなく なり, 街頭ビジョンの印象が強く残ってしまうことが原因であると 推察される. 街頭ビジョンが減ると壁面広告が多い場合に賑わい感 が増加した. 街頭ビジョンの総量が減少すると壁面広告の影響が増 すことが推察された.

表 10 に, 快適感を規定する要因の結果を示す。快適感では, 街頭 ビジョン $(\mathrm{F}(3,129)=65.2, \mathrm{p}<.01)$ において主効果が有意であった. また，有意な交互作用は検出されなかった．街頭ビジョンが $14 \%$ の ときに負の最大值をとっており，不快に感じていることが把握され た。また，もっとも快適であるとされたのは街頭ビジョンが $0 \%$ の 場合ではなく, 街頭ビジョンの割合が小さい場合であった。これは, 街頭ビジョンが完全になくなった状態よりも多少なりとも存在して いる場合の方が心地よいと感じていることを示している. また, 負 の効果值を示したのは街頭ビジョン $14 \%$ の場合のみであったことか ら，秩序をもった街頭ビジョンの配置を心がけることで，不快感を 軽減することができると考えられる。

表 11 に，明るさ感を規定する要因の結果を示す，明るさ感 では，街頭ビジョン $(\mathrm{F}(3,129)=318.7, \mathrm{p}<.01)$ 及び壁面広告 $(\mathrm{F}(1,129)=42.0, \mathrm{p}<.01)$ において主効果が有意であった. 街頭ビジ ヨンが $0 \%$ のきに負の最大值, 街頭ビジョンが $14 \%$ のきに正の 最大值をとっており, 街頭ビジョンが少ないほど暗く, 多いほど明 るい印象を受けることが分かった。また，壁面広告に関しても同様 の傾向を示しており，視界に入る広告物の割合が大きいほど明るい 印象を受けていると推察される。また，街頭ビジョンと屋上広告塔 の交互作用 $(\mathrm{F}(3,129)=13.5, \mathrm{p}<.01)$ ，街頭ビジョンと壁面広告の交
Table 10 INFLUENCE FACTORS OF COMFORTABLE

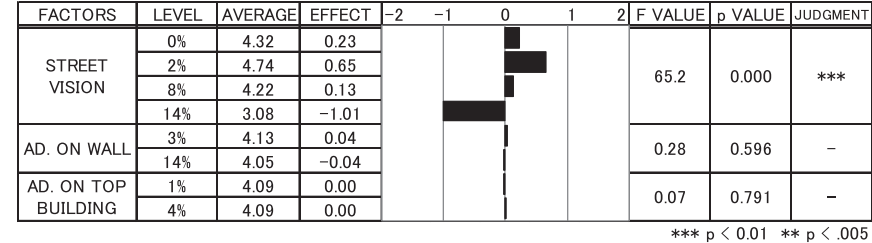

Table 11 INFLUENCE FACTORS OF BRIGHTNESS

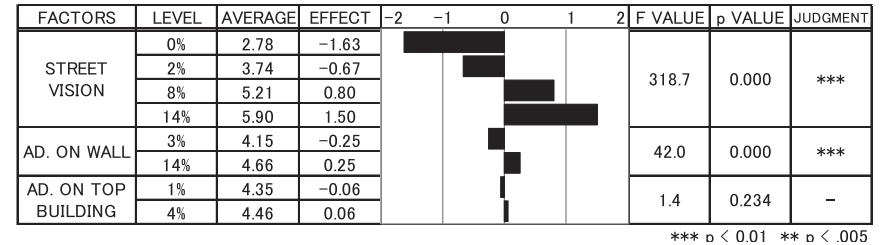

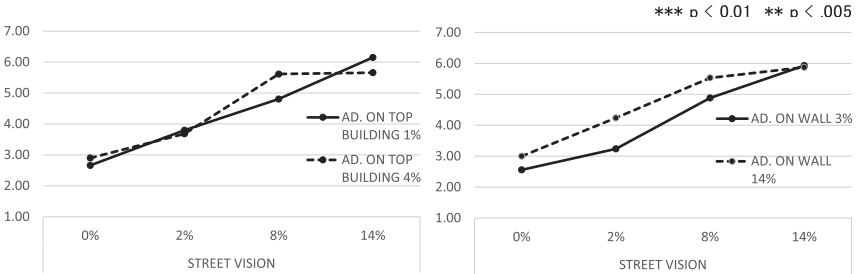

Fig. 17 BRIGHTNESS BETWEEN Fig. 18 BRIGHTNESS BETWEEN VISION AND AD. ON TOP BUILDING VISION AND AD. ON WALL

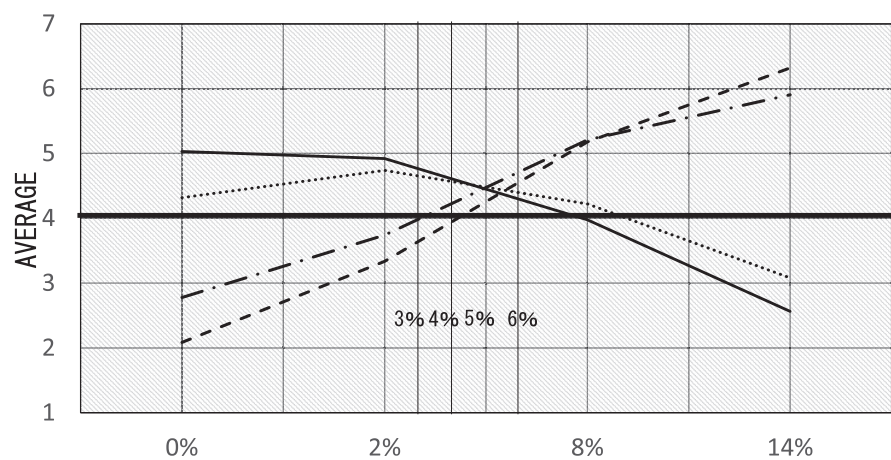

—UNITY - - BUSTLING …... COMFORTABLE - BRIGHTNESS

Fig. 19 PERCENTAGE OF STREET VISION AND LANDSCAPE EVALUATIONS

互作用 $(\mathrm{F}(3,129)=7.9, \mathrm{p}<.01)$ において有意差が確認されたため, 単純主効果の検定を行った。図 17 に, 街頭ビジョンと屋上広告塔に 屋上広告塔別の明るさ感の推移を示す．街頭ビジョンが $0 \%, 2 \%$ の とき，屋上広告塔の変化に有意差が見られなかった，これは，視界 に入る街頭ビジョンの割合が大きい多い場合に比べ，小さい場合の 暗い印象が強く, 屋上広告塔の数の変化に影響されずに街頭ビジョ ンの数の変化のみで明るさ感の評価がおこなわれていることが原因 として考えられる，図 18 に，街頭ビジョンと壁面広告の明るさ感の 関係を示す．評価值の推移から，街頭ビジョンが 14\%のとき，壁面 広告の変化に有意差が見られなかった。これは，視界に入る街頭ビ ジョンの割合が大きい場合には, 明るさが街頭ビジョンに依存して おり, 周囲に存在しているはずの壁面広告の変化の影響を一切受け ずに明るさ感の判断をおこなっていることが原因であると推察され る.

\section{5 屋外街頭ビジョンの設置割合と景観評価の関係}

図 19 に, 街頭ビジョンの設置割合の水準に応じた 4 つの評価尺度 の平均值を示す，屋外広告物の中で屋外街頭ビジョンの影響が大き いことから, まとまり感, 賑わい感, 快適感, 明るさ感の評価尺度 別に建物ファサード全体における街頭ビジョンの設置水準の割合と 
評価尺度の関係を考察する. 図 19 の中で, 縦軸の 7 段階で 4 より大 きい場合は各尺度に対する正の効果を, 4 より小さい場合は負の効 果を持つ. まとまり感では, 街頭ビジョンの設置割合が $8 \%$ 以下であ る場合に正の効果值が確認された。これは, 建物ファサード全体に おける $8 \%$ 以下の設置割合の時に, 景観のまとまり感を保つことが できることを示している，賑わい感では，4\%以上の設置割合である とき, 正の効果值が確認された。これは, 賑わい感を向上させるた めには，4\%以上，視界に入る街頭ビジョンの割合を増やすことが 好ましいと言える，以上より，建物ファサード全体における $4 \%$ 以 上の割合の変化において, まちなみの賑わい感を保つことができる. 快適感では，正の值から負の值への切り替わりが $8 \%$ と $14 \%$ の間に 見られた．また，正の最大值を示したのは $2 \%$ の場合であった。快 適感を向上させるためには, 街頭ビジョンを適度に設置することが 好ましい，街頭ビジョンの設置割合が約 $9 \%$ 以下である場合，正の 効果值が確認されたことから，視界に入る街頭ビジョンの割合を大 き過ぎることで負の影響が出ることが考えられる. 以上より, 建物 ファサード全体における $9 \%$ 以下程度の割合の変化において，まち なみの快適感を保つことができる，明るさ感では， $3 \%$ 以上の設置割 合である時，正の効果值が確認された，明るさ感を向上させるため には，視界に入る街頭ビジョンの割合を大きくすることが好ましい. 建物ファサード全体における街頭ビジョンの割合を $3 \%$ 以上確保す ることで，明るい印象を得ることが確認された。

図 19 の 4 つの評価尺度の交点は, 設置割合が $5 \%$ から $5.5 \%$ の時 であった．この時，全効果值が正であることから，4つの評価尺度 をすべてポジティブに満足するため, 均衡点であることが把握され た． 4 尺度を同時にポジティブに満足寸る均衡点は $5 \%$ から $5.5 \%$ で あることが確認された。

各評価尺度の範囲で考える場合，まとまり感を得るには街頭ビジ ヨンの設置割合を $8 \%$ 以下，快適感を得るには $9 \%$ 以下，賑わい感を 得るには $4 \%$ 以上，明るさ感を得るには $3 \%$ 以上と考えることができ る. 4 つの評価尺度を最低限に満足し，大きな問題を生じないと考 えられる許容範囲は $4 \%$ 以上 $8 \%$ 以下であることが明らかになった.

以上から，街頭ビジョンの景観形成指標として設置割合の上限を 定める時, 均衡点である $5 \%$ から $5.5 \%$ とすることが望ましい. 許容 範囲としては，設置割合を $8 \%$ 以下とすることで大きな問題が生じ にくいと考えることができる.

\section{4. まとめ}

以上, 屋外街頭ビジョンがある駅前交差点周辺の景観評価を規定 する要因を明らかにした結果，下記の 3 点が明らかになった.

1）駅前交差点周辺の景観評価は，屋外広告物による影響を強く受け ており，壁面広告や屋上広告塔よりも街頭ビジョンの影響が最も強 いことが確認された.

2）駅前交差点周辺の景観評価では, 賑わい感と明るさ感は広告物の 割合に比例して, まとまり感と快適感は広告物の割合に反比例して 影響が変化することが確認された。また，賑わい感と明るさ感は街 頭ビジョンの設置割合が高い場合に高まり，まとまり感と快適感は 街頭ビジョンの設置割合が低い場合に高まることが把握された，

3）ターミナルとなる駅前交差点周辺では, 街頭ビジョンの設置割合 $2 \%$ で快適感が最大となるなど，街頭ビジョンが無いよりあった方が
望ましく, 設置割合 $5 \%$ から $5.5 \%$ の場合に 4 尺度を満足する均衡点 となり，この水準を超えるとまとまり感や快適感の点でマイナス面 が目立ってきて，設置割合 $8 \%$ で許容範囲の限界となる。

以上の知見より, 駅前交差点周辺の景観形成指標として街頭ビジ ヨンの設置割合の上限は，均衡点である $5 \%$ から $5.5 \%$ とすることが 望ましく，許容範囲としては $8 \%$ 以下とすることが妥当である.

\section{謝辞}

本研究における実験の実施は, 当時, 茨城大学工学部都市システ ム工学科 4 年生であった関川弘樹君によるところが大きい．ここに 記し，深くお礼を申し上げる。

\section{参考文献}

1)Article posted on Website Outdoor street visions.com, accessed 2018.10.3.(in Japanese) Website 大型ビジョン .comに掲載された記事, http://oogata-vision. com/index.html, 2018.10.3 参照

2)Article posted on Website Shibuhachihit, accessed 2018.10.3.(in Japanese) シブ 八 チヒットに掲載された記事, http://www.hit-ad.co.jp/newmedia/shibuyaled.html, 2018.10.3 参照

3)Shibuya-ku:Landscape design Guidelines in Shibuya-ku,2013.3,accessed 2018.10.3.(in Japanese)

渋谷区都市整備部都市計画課土地利用審査係: 渋谷区景観形成ガイドライン 2013.3, https://www.city.shibuya.tokyo.jp/assets/detail/files/kurashi_machi_pdf_ keikan_guide.pdf, 2018.10.3 参照

4) Ryo KATO, Haruhiko GOTO and Kiyomasa BABA:The Current Installation of Digital Signage within the Urban Cityscape, Journal of the the City Planning Institute of Japan, Vol.49, No.3, pp.717-722, 2014.10.(in Japanese)

加藤瞭, 後藤春彦, 馬場健誠 : 繁華街におけるデジタルサイネージの掲出実 態 一 銀座地区の店舗表層に現れる映像広告物の全数調査一, 日本都市計画 学会都市計画論文集，49 巻 No.3, pp.717-722, 2014.10.

5) Takumi MATSUSHITA and WATANABE Shun: A study on Possibility of Largescale vision as regional information dissemination tool, Proceeding of Architectura Research Meetings, Kanto Chapter, Architectural Institute of Japan II, pp.445-448, 2012.3. (in Japanese)

松下拓未，渡辺俊：地域情報発信ツールとしての大型ビジョンの可能性に関 する研究, 日本建築学会関東支部研究報告集 II, pp.445-448, 2012.3.

6) Mitsru YAMAGUCHI, Hideki SHIMIZU and Nobuhiro SUZUKI: Relational Structures between physical Elements' Favorability and Total Evaluations in Station Plazas, Journal of Architecture, Planning and Environmental Engineering (Transactions of AIJ), No.467, pp.89-96, 1995.1. (in Japanese)

山口満，志水英樹，鈴木信弘：駅前広場における好ましさと全体景観の評価 との関連構造に関する研究，日本建築学会計画系論文集，第 467 号，pp.8996, 1995.1

7) Tomohiro SHIMIZU, Shin YOSHIKAWA and Kazunari TANAKA; Analysis of Visual Effects by Billboard, Papers and proceedings of the Geographic Information Systems Association, No.16, pp.371-374, 2007.10.(in Japanese) 清水智弘, 吉川眞, 田中一成: 屋外広告物による視覚的影響の分析, 地理 情報システム学会講演論文集, No.16, pp.371-374, 2007.10.

8) Naoyuki OI, Takaya KOJIMA, Takaaki KOGA, Jun MUNAKATA and Kotaroh HIRATE: A study on the Standardization of Words for the Evaluation of TownscapeClassification of Words and Several Problem, Summaries of Technical Papers of Annual Meeting, Architectural Institute of Japan, D-1, pp.789-790, 1997.9.(in Japanese)

大井尚行，小島隆矢，古賀誉章，宗方淳，平手小太郎：景観評価尺度の標準 化に関する研究 : 尺度の整理および検討課題の提起，日本建築学会大会学術 講演梗概集 , D-1，pp.789-790，1997.9

9) Katsunori OKAJIMA and Mitsuo IKEDA; Relation of Corresponding Color in a Surface Color Mode and a Luminous Color Mode, Japanese Jounal of Optics, The Optical Society of Japan, No.20-6, pp.363-368, 1991.6.(in Japanese) 岡嶋克典, 池田光男 : 表面色モードと光源色モードにおける対応色の関係, 光学, 第 20 巻, 第 6 号, pp.363-368, 1991.6. 


\title{
FACTORS INFLUENCING LANDSCAPE EVALUATIONS AROUND AN INTERSECTION IN FRONT OF A STATION WITH OUTDOOR STREET VISONS
}

\author{
Takayuki KUMAZAWA*1 and Daiki TAKADA*2 \\ ${ }^{* 1}$ Assoc. Prof., College of Engineering, Ibaraki Univ., Dr.Eng. \\ ${ }^{* 2}$ Chuoh Consultants Co., Ltd., M.Eng.
}

\begin{abstract}
In recent years, as the size of displays have become larger, the number of installed outdoor street vision around station intersections have increased year by year. However, there are not sufficient rules to regulate outdoor street vision. Besides, there are no previous studies that have quantitatively examined the causal relationship between physical environmental factors and psychological evaluation of the landscape with outdoor street vision. It is necessary to quantitatively consider the relationship between the physical environmental factors of outdoor street vision and human reactions. In addition, it is necessary to demonstrate concrete guidelines in order to maintain an attractive landscape. Therefore, landscape simulation experiments were conducted using a 1:100 model, in which physical environmental factors such as the number of installed street vision and its size were changed. Subsequently, based on the obtained data, the factors that prescribe landscape evaluation are quantitatively examined.
\end{abstract}

As a result of clarifying the factors that regulate landscape evaluation around the intersection of a station with outdoor street vision, the following three points were observed.

1) Landscape evaluation around station intersections was strongly influenced by outdoor advertisements. Furthermore, it was confirmed that the influence of outdoor street vision is stronger than those of wall advertisements and rooftop advertisement towers.

2) As a result of evaluating the landscape around the intersection in front of a station, it was confirmed that the feeling of bustle and sense of brightness increase in proportion to the size of the advertisements. Consequently, it was confirmed that the sense of cohesion and comfort decreased in inverse proportion to size of the advertisements. In addition, the bustle and brightness feelings increase when the installation ratio of the outdoor street vision is high, while the sense of cohesiveness and comfort are increased when the installation ratio of the outdoor street vision is low.

3) In the vicinity of the intersection in front of the station, the comfortable feeling is maximum with the installation ratio of the street vision of $2 \%$. It would be better if there was no street vision than there was not. The installation ratio $5 \%$ to $5.5 \%$ is an equilibrium point that satisfies 4 scales. When this level is exceeded, the downside is conspicuous in terms of cohesiveness and comfort. It is the limit of the allowable range with the installation ratio of $8 \%$.

Based on the above findings, a landscape formation index around the station crossing is described. The upper limit of the percentage of street vision to be installed should be $5 \%$ to $5.5 \%$, which is the equilibrium point. It is reasonable to set the allowable range to $8 \%$ or less. 